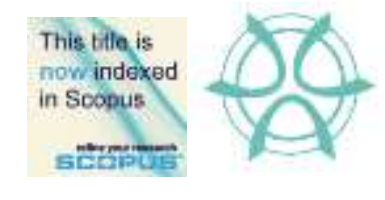

PLANNING MALAYSIA:

Journal of the Malaysian Institute of Planners

VOLUME 19 ISSUE 2 (2021), Page 1 - 13

\title{
RETHINKING DENSITY IN URBAN PLANNING: POLICY DIRECTIONS IN THE POST-COVID-19 ERA IN MALAYSIA
}

\author{
Seng Boon Lim ${ }^{1}$, Jalaluddin Abdul Malek ${ }^{2}$, \\ Mohd Fadzil Abdul Rashid ${ }^{3}$ \& Yong Chee Kong ${ }^{4}$ \\ ${ }^{1,2}$ Centre for Research in Development, Social and Environment, \\ Faculty of Social Sciences and Humanities \\ UNIVERSITI KEBANGSAAN MALAYSIA \\ ${ }^{3}$ Department of Built Environment Studies \& Technology, \\ Faculty of Architecture, Planning and Surveying \\ UNIVERSITI TEKNOLOGI MARA, PERAK BRANCH, MALAYSIA \\ ${ }^{4}$ PLANMalaysia (Federal Department of Town and Country Planning) \\ MINISTRY OF HOUSING AND LOCAL GOVERNMENT, MALAYSIA
}

\begin{abstract}
Since the 'Coronavirus Disease 2019' (COVID-19) struck the world and Malaysia, the general attention of the media and leaders has been focused on the high population density areas that have high infection rates and deaths. This article aims to rethink population density in urban development policy, thus providing development for policy direction in the post-COVID-19 era in Malaysia. The available national development planning policies in Malaysia, i.e., the National Physical Plan and the National Urbanisation Policy, and scholarly articles related to the population density topic were investigated through a scoping literature review and a keyword analysis. The findings showed mixed results in terms of the relationship between dense areas causing higher rates of COVID-19 infection and death rates. This article argues that policies related to spatial urban planning should continuously advocate dense city planning in considering how to achieve economic, social, and environmental sustainability and human quality of life. To this extent, this article contributes to the densification topic in spatial urban planning policies in terms of their application in the post-COVID-19 era, which needs urgent direction and clarification.
\end{abstract}

Keywords: City planning, pandemic intervention, density planning, human connectivity, crowding and order, social distancing, coronavirus outbreak

\footnotetext{
${ }^{1}$ Associate Professor at Universiti Kebangsaan Malaysia. Email: jbam@ukm.edu.my
} 
Seng Boon Lim, Jalaluddin Abdul Malek, Mohd Fadzil Abdul Rashid \& Yong Chee Kong

Rethinking Density in Urban Planning: Policy Directions in the Post-Covid-19 Era in Malaysia

\section{INTRODUCTION}

Since the outbreak of Coronavirus in Wuhan, China in December 2019 until today, various public media and statistics have reported that dense areas are some of the spots highlighted that tend to bring closer human contact, facilitating the spread of coronavirus and thus possibly causing deaths (ourworldindata.org, 2021). On the international level, the New York Times reported that "The pandemic has been particularly devastating to America's biggest cities, as the virus has found fertile ground in the density that is otherwise prized" (Tavernise \& Mervosh, 2020). CNN's article quoted the governor's expression, "It's very simple. It's about density. It's about the number of people in a small geographic location allowing that virus to spread.... Dense environments are its feeding grounds" (Shoichet \& Jones, 2020).

In the local level media, the tone is similar to that of the international level. The Malay Mail quoted the Chief Minister of Selangor: "Population density among causes of high Covid positive cases in Selangor" (Malaymail, 2021). A town planner, writing in the Star, expressed the view that "COVID-19 may well disappear in a few years like many a pandemic before it, but it is teaching town planners a valuable lesson. Not through any particular uniqueness as a biological entity, but by the simple fact that disease spreads more easily among populations living in close quarters. Now is the time to get that into reverse gear" (Gunasilan, 2020). The official website of the Ministry of Health Malaysia stated that, "Although the CMCO (conditional movement control order) has averted the exponential surge of cases in Selangor and brought down the Ro [i.e., the average number of secondary cases that result from one infected person] from 2.2 to 1.4, the daily cases continue to increase slowly and consistently. Our concern is the high density and mobility of the people, plus we cannot test everyone coming out of the red zones" (Ministry of Health for Malaysia, 2020).

Thus, amid the COVID-19 outbreak, these media reports have raised concerns about population density, which is of the utmost concern in the spatial urban planning dimension and its policy design. The fundamental spatial planning principle that is dedicated to the quality of life, economic scales, and sustainable development opts for dense populations or compact city planning, thus avoiding urban sprawl (Hamidi et al., 2020). However, the density dilemma is that high urban density creates ideal conditions for the expansion of disease; at the same, cities also work as laboratories to defeat disease (Keil, 2020). Therefore, will the term 'density' be oversimplified by the media and cause worries and confusion to the urban planning doctrine and the post-COVID-19 urban development policy direction? Will the cause be not density but other factors, such as crowding, that matter for curbing the spread of the deadly coronavirus? (Jun, 2020). In answering these two research questions, this article seeks to investigate the relationship between the COVID-19 pandemic outbreak 
and the population density, and suggest a pathway for post-COVID-19 urban development policy and professional practices.

The following section explains the methodology adopted in this study. Then, followed by the findings from the top-down policies, namely the Third National Physical Plan (NPP3) and the Second National Urbanisation Policy (NUP2), the selected scholarly articles were compared and analysed. The section ends with discussions on the possible suggestions for urban development policy and professional practices, and provides a conclusion covering the potential limitations and contributions of the paper, and further studies.

\section{METHODOLOGY}

This article applied the scoping literature review and keyword analysis methods. The scoping review method aims to extract as much relevant data or information as possible related to a predetermined scope (Peters et al., 2015). The review was not exhaustive but sufficient to cover the research scope. The scope set for this study was within the range of the COVID-19 pandemic phenomena in Malaysia and the population density. Using the Google search engine, keywords selected for the scoping searches included "COVID-19", "density", "Malaysia", "quality of life", and "urban planning". For the keyword analysis, the AntConc software was utilised for the 'density' keyword occurrence and co-occurrence count in selected documents. The findings were then presented in three parts: the overview of COVID-19 that led to a change in lifestyle, national urban planning policies, and scholarly articles related to COVID-19 and density.

\section{FINDINGS}

\section{Current Outbreak of COVID-19, Work from Home and Lifestyle Changes}

As of July 9, 2021, COVID-19 has claimed nearly 4 million lives worldwide and six thousand lives in Malaysia (WHO, 2021). People are curious about how long the COVID-19 pandemic will last, and a prediction could refer to previous pandemics, which typically lasted between 12 and 36 months (Krouse \& Miller, 2021). Hence, counted from the first confirmed COVID-19 case in Wuhan, China, by the World Health Organization (WHO) on January 12, 2020, the estimated end date of COVID-19 would be around the end of 2022 with the effective worldwide vaccine injections.

During the COVID-19 pandemic period, strict movement controls were applied in various countries to curb the spread of the COVID-19, including Malaysia. However, these attempts at movement control, such as prohibition from crossing countries, states, and districts; avoiding confined and enclosed spaces; and social distancing of one to two metres to prevent close human contacts, have impacted people's lives (Lim, 2020). Nearly one-third of people's quality of life is at stake during the movement controls (UNDP, 2020), as visits 
Seng Boon Lim, Jalaluddin Abdul Malek, Mohd Fadzil Abdul Rashid \& Yong Chee Kong

Rethinking Density in Urban Planning: Policy Directions in the Post-Covid-19 Era in Malaysia

to confined and enclosed public areas, including shopping malls, restaurants, schools, and streets, are not advisable. Technically, the socialising space has been limited to the private space of one's home, and this has eliminated all the public spaces and social constructs that have been built for people. Thus, most family members are facing a sudden loss of community socialising and involvement (i.e., social isolation) and are forced to learn, work and play from their home, which is widely known as Work from Home (WFH) or even Life at Home (Bogle, 2020). People's lifestyles have been disrupted by the COVID-19, and a new normality is ahead. As lifestyles change, planning for a better quality of life in the postCOVID-19 era and upholding the new normality is essential, as the quality of life is always the ultimate aim in urban planning and development (Jun, 2020).

\section{The Third National Physical Plan (2016-2020) (NPP3) and The Second National Urbanization Policy (2016-2025) (NUP2)}

Under the national top-down plans, the authors analysed the keyword 'density'. The authors found that the concept of 'density' was not explained well in either the NPP3 or the NUP2. In the National Language version of NUP2, the terms 'density' or 'dense' (in Malay, kepadatan and padat) occur only eight times. The 'density' co-occurrence is related to two main themes: 1) the smart growth that supports high-density city development, transit-oriented development (TOD), mixed land-use development, and avoids urban sprawl, and 2) the high-density economy.

In the NPP3, the term occurred 18 times. Like the NUP2, the 'density' co-occurrence is related to high-density development. It argues that high-density development in urban areas generates economic activities in the cities, especially in the sectors of industry, commerce, and services by increasing the gross domestic product. Particularly in NPP3: Chapter 4, the 'density' keyword appears 14 times, and the example given for encouraging high-density development is that Kuala Lumpur city centre was redeveloping Pudu Jail into a high-density mixed-use development (KPKT, 2016, pp. 4-64). Besides, the discussion also reflects the population density in Peninsula Malaysia and Sabah. As of 2013, the density of the Peninsula is 8 persons/ac, which is slightly higher than Sabah, where it is 7 persons/ac (Table 1). This indicates a lower density level, and there is high potential in promoting Malaysia to become a higher-density country incorporating many large city centres.

Table 1: Population density in Peninsula Malaysia and Sabah

\begin{tabular}{lcccc}
\hline & \multicolumn{3}{c}{ Peninsula Malaysia } & Sabah \\
\hline & $\mathbf{2 0 0 5}$ & $\mathbf{2 0 1 0}$ & $\mathbf{2 0 1 3}$ & $\mathbf{2 0 1 3}$ \\
\hline Percentage of Built-up area (\%) & 3.32 & 5.76 & 8.91 & 2.49 \\
\hline Population (million) & 18.52 & 18.52 & 22.57 & 3.20 \\
\hline
\end{tabular}


PLANNING MALAYSIA

Journal of the Malaysia Institute of Planners (2021)

\begin{tabular}{lcccc}
$\begin{array}{l}\text { Density (population upon built- } \\
\text { up area in acre) }\end{array}$ & 17 & 10 & 7 \\
\hline
\end{tabular}

In addition, under action KD2.1B of the Spatial Sustainability domain, the NPP3 policy is to apply development with 'sustainable density' (in Malay, berdensiti mampan) (KPKT, 2016, pp. 4-66). 'Sustainable' in this sense was translated as being high- to medium-density for development control, but without a clear operational definition of how to work with it. It postulated that a 'sustainable measure of density' plays a role in supporting the sustainable development agenda, liveability, and resilience of NPP3. Other than providing some aspects of high-density development, including the TOD, mixed-use development, and being a walkable city (KPKT, 2016, pp. 4-66), the policy stated that the degree of 'density' should be determined by local authorities (LAs) of each city. For the authors, this notably lacks clear top-down direction and will definitely increase confusion among LAs in self-judging the density criteria.

On the other hand, under action KD2.2: Managing a high-risk natural disaster area, the NPP3 mentioned that natural disasters tend to happen frequently if not properly controlled, and such impacts always occur in high-density areas (KPKT, 2016, pp. 4-72). For the authors, this leads to contradictions at the execution level, since action KD2.1B asks LAs to select high-density development, but in action KD2.2, a high-density development tends to be exposed to the risk of natural disaster. What is the control measure behind the situation that means responsibility is shouldered by the LAs? Again, all statements seem entirely dependent on local contexts, but there is no explicit mention of how to put it into practice. The authors foresee that, with these topdown contracting policies, the ability of LAs to translate such 'sustainable density' into high-density development is crucially important. Still, most of them are at a crossroads in terms of the need to make good decisions with limited human and financial resources (Bahardin et al., 2019). In addition, the NPP3 policy stated that low-density development is always related to non-sustainable factors contributing to urban sprawl (KPKT, 2016, pp. 4-66). To shed light on the statement, three issues would occur. First, how does sustainable development mean high density, and should LAs always look and approve those high densities or mixed-use developments? Second, how high is high-density in their local contexts, since a benchmark standard was not provided in the NPP3? Third, should LAs go for high-density, as most people wish to stay in medium to lowdensity areas in their imagined city centre lives? These issues shall be further discussed in the following sections of this article. 
Seng Boon Lim, Jalaluddin Abdul Malek, Mohd Fadzil Abdul Rashid \& Yong Chee Kong

Rethinking Density in Urban Planning: Policy Directions in the Post-Covid-19 Era in Malaysia

\section{Reviews on Scholarly Articles Related to Density and Covid-19}

High population density planning seems utopian as a sustainable type of development, considering its economic viability, and communication and transportation technology enhancement. However, this was not until the current outbreak of COVID-19, after which the media commented that the density could be a cause of the spread of COVID-19. This matter is the main concern of this article. This subsection reviews the scholarly articles and attempts to answer the research questions formed in the introductory section:

1) Is the term 'density' being oversimplified by the media, causing confusion for the post-COVID-19 urban planning policy direction?

2) Could it be not the density but other factors that matter in curbing the spread of the deadly coronavirus in terms of urban planning?

To answer the first research question, the authors found that it is crucial to define the meaning of 'density'. Generally, urban density is a concept used in urban studies, and related fields to describe the intensity of people, housing units, the total floor area of buildings, or some other measure of human occupation, and activity across a defined unit of area. There are various ways of defining the density of urban areas, namely site/parcel density, block density, net density, residential density, net residential building type density, gross density, city or municipal density, coverage ratio of neighbourhood and sub-area, metropolitan density and even employment density (Jenks \& Dempsey, 2005; Rapoport, 1975).

In the media's description, urban density is generalised to the degree of concentration of people in a city. The high density of urban populations increases with the activities of people. Therefore, the likelihood of a COVID-19 infector and infectee coming into close contact is higher. This preliminary understanding is not incorrect but should be interpreted with caution because it mostly lacks a rigid definition of density, methodology and remains hypothetical. The media would mislead the public and offer implausible perceptions to planners that there is 'something wrong' with the high-density development belief and that future development should possibly opt for low-density development.

The above explanation leads to the second question, for which the reviews of scholarly articles showed mixed results. In the review of economic studies, i.e., Wheaton and Thompson (2020b, 2020a), with direct and straightforward statistical methods, it was found that they tend to prove density influences the spread of the pandemic. The same case happens in sources in geographical studies, i.e., Rahman et al. (2020) and Ramírez-Aldana et al. (2020), which confirmed the spatial (density of population) factor is correlated significantly to the COVID-19 spread. In this case, the geographical modelling studies tend to generalise the spatial only in two-dimensional views, thus ignoring the fact that density usually happens in a vertical dimension. On the other hand, 
articles which include rigid testing, i.e., Almagro and Orane-Hutchinson (2020), Carozzi et al. (2020) and Hamidi et al. (2020), explained further that it is not density that is directly causing the spread of the virus, but other confounding factors are involved. The factors included are connectivity, crowding, and order.

In other words, in a high-density area, the spread of the pandemic virus does not necessarily increase if the contact between humans is maintained at a safe social distance. The connections or network linkages between domestic, commercial, industrial and logistical activities are necessary for economic purposes, but if they are under control and in order, and overcrowding can be avoided, the spread of the virus would also be prevented. This is the case in Singapore (Salama, 2020). On the contrary, in low-density rural areas with uncontrolled human behaviour, if disorderly daily connectivity activities happen simultaneously, with meetings, gatherings and allowing big crowds, such as in West Africa (Connolly et al., 2020), then perhaps the infection rate will be higher than in a high-density area. Further explanations of the results and observations of the reviews are shown in Table 2.

Table 2. Reviews of scholarly articles on population density and COVID-19

\begin{tabular}{|c|c|c|c|}
\hline Scholar & Methodology & Finding & Observation \\
\hline $\begin{array}{l}\text { Wheaton } \\
\text { and } \\
\text { Thompson } \\
(2020 \mathrm{~b})\end{array}$ & $\begin{array}{l}\text { Used data from cities } \\
\text { in Massachusetts to } \\
\text { provide a cross- } \\
\text { sectional analysis of } \\
\text { the per capita } \\
\text { infection rate. }\end{array}$ & $\begin{array}{l}\text { Found that population } \\
\text { density has an economically } \\
\text { and statistically significant } \\
\text { positive effect on the } \\
\text { incidence of the disease. }\end{array}$ & $\begin{array}{l}\text { The statistical analysis } \\
\text { and regression were } \\
\text { direct, and other } \\
\text { controlling factors were } \\
\text { not analysed. }\end{array}$ \\
\hline $\begin{array}{l}\text { Wheaton } \\
\text { and } \\
\text { Thompson } \\
(2020 a)\end{array}$ & $\begin{array}{l}\text { A continuous cross- } \\
\text { sectional analysis } \\
\text { from previous } \\
\text { publications, from } \\
\text { April to May } 2020 \text {. }\end{array}$ & $\begin{array}{l}\text { Again, they found that } \\
\text { councils with greater density } \\
\text { and a greater share of land } \\
\text { use in commercial categories } \\
\text { have a higher per capita } \\
\text { incidence of the disease. }\end{array}$ & As above. \\
\hline $\begin{array}{l}\text { Ramírez- } \\
\text { Aldana et } \\
\text { al. (2020) }\end{array}$ & $\begin{array}{l}\text { The analyses applied } \\
\text { to cumulative cases } \\
\text { of the disease in Iran } \\
\text { through a Bayesian } \\
\text { technique and } \\
\text { relative risks. }\end{array}$ & $\begin{array}{l}\text { Urbanised, highly connected } \\
\text { provinces with older } \\
\text { population structures and } \\
\text { higher average temperatures } \\
\text { were the most susceptible to } \\
\text { presenting a higher number } \\
\text { of COVID-19 cases. }\end{array}$ & $\begin{array}{l}\text { The geographical } \\
\text { analysis generalised the } \\
\text { spatial in a two- } \\
\text { dimensional view and } \\
\text { potentially ignored that } \\
\text { density is counted } \\
\text { vertically in reality. }\end{array}$ \\
\hline $\begin{array}{l}\text { Rahman et } \\
\text { al. (2020) }\end{array}$ & $\begin{array}{l}\text { Data at the district } \\
\text { level in Bangladesh } \\
\text { were analysed } \\
\text { through a spatial } \\
\text { regression model } \\
\text { (SRM). }\end{array}$ & $\begin{array}{l}\text { Four factors significantly } \\
\text { affected the COVID-19 } \\
\text { incidence rates in } \\
\text { Bangladesh: urban } \\
\text { population, monthly } \\
\text { consumption, number of }\end{array}$ & $\begin{array}{l}\text { As above. It is worth } \\
\text { noting that a greater } \\
\text { distance from the capital } \\
\text { city would mean the } \\
\text { pandemic spreads, } \\
\text { because it pushes people }\end{array}$ \\
\hline
\end{tabular}


Seng Boon Lim, Jalaluddin Abdul Malek, Mohd Fadzil Abdul Rashid \& Yong Chee Kong

Rethinking Density in Urban Planning: Policy Directions in the Post-Covid-19 Era in Malaysia

\begin{tabular}{|c|c|c|c|}
\hline & & $\begin{array}{l}\text { health workers, and distance } \\
\text { from the capital. }\end{array}$ & $\begin{array}{l}\text { to leave their home } \\
\text { places. }\end{array}$ \\
\hline $\begin{array}{l}\text { Almagro \& } \\
\text { Orane- } \\
\text { Hutchinson } \\
(2020)\end{array}$ & $\begin{array}{l}\text { Examined the data } \\
\text { on the number of } \\
\text { tests and positives } \\
\text { across New York } \\
\text { City (NYC) zip } \\
\text { codes. }\end{array}$ & $\begin{array}{l}\text { Found a significant positive } \\
\text { relationship between } \\
\text { population density and the } \\
\text { share of positive tests, but } \\
\text { this relationship seems to } \\
\text { decline over time. Crowded } \\
\text { spaces play a more } \\
\text { important role than } \\
\text { population density in the } \\
\text { spread of COVID-19. }\end{array}$ & $\begin{array}{l}\text { Through a rigid } \\
\text { statistical test in this } \\
\text { study, the conclusion is } \\
\text { essential in clearing the } \\
\text { doubt that it is a } \\
\text { 'crowded space' (or } \\
\text { inevitable physical } \\
\text { distance) but less so the } \\
\text { 'population density' that } \\
\text { spreads the coronavirus. }\end{array}$ \\
\hline $\begin{array}{l}\text { Carozzi et } \\
\text { al. }(2020)\end{array}$ & $\begin{array}{l}\text { Quantitative } \\
\text { methods; case study } \\
\text { of } 1759 \text { counties in } \\
\text { the United States, } \\
93 \% \text { of the total U.S. } \\
\text { population. }\end{array}$ & $\begin{array}{l}\text { Density affected the timing } \\
\text { of the outbreak, with denser } \\
\text { locations more likely to have } \\
\text { an early outbreak. However, } \\
\text { no evidence was found that } \\
\text { population density is } \\
\text { positively associated with } \\
\text { the time-adjusted number of } \\
\text { COVID-19 related deaths. } \\
\text { This study cast doubts on } \\
\text { hasty predictions of the } \\
\text { consequences of dense urban } \\
\text { living. }\end{array}$ & $\begin{array}{l}\text { The statistical } \\
\text { comparison methods by } \\
\text { Carozzi et al. (2020) are } \\
\text { convincing, where } \\
\text { controlling the } \\
\text { confounding factors } \\
\text { yields the result that } \\
\text { deaths are not affected } \\
\text { by density but crowding } \\
\text { differences in preventive } \\
\text { measures, and access to } \\
\text { healthcare; demographics } \\
\text { may contain the spread. }\end{array}$ \\
\hline $\begin{array}{l}\text { Hamidi et } \\
\text { al. (2020) }\end{array}$ & $\begin{array}{l}\text { Use of structural } \\
\text { equation modelling } \\
\text { to account for } \\
\text { impacts of density } \\
\text { on the COVID-19 } \\
\text { infection and } \\
\text { mortality rates for } \\
\text { U.S. metropolitan } \\
\text { counties }\end{array}$ & $\begin{array}{l}\text { Documents a flat } \\
\text { relationship between density } \\
\text { and the infection rate after } \\
\text { controlling for population. } \\
\text { Connectivity matters more } \\
\text { than density. They } \\
\text { recommended that planners } \\
\text { should continue to advocate } \\
\text { dense development. }\end{array}$ & $\begin{array}{l}\text { These findings, in } \\
\text { suggesting that } \\
\text { connectivity matters } \\
\text { more than density in the } \\
\text { spread of the COVID-19 } \\
\text { pandemic, are valid } \\
\text { evidence for a rethinking } \\
\text { of the density issue in } \\
\text { urban development. }\end{array}$ \\
\hline
\end{tabular}

\section{DISCUSSIONS}

From the keyword analysis, both the NUP2 and NPP3 policies advocated a highdensity development direction. However, as aforementioned, a lack of clear direction in terms of 'density' was found in the policies. The NPP3 stated that the actual density of development should be dependent on the judgment of LAs regarding environmental effects and people's lives. This would lead to uncertain actions and contradictory spatially urban planning decisions among LAs and other urban sectors. Furthermore, the analysis of the scholarly articles showed mixed results. Those geographical modelling and economic studies with direct 
statistical methods supported the media hypothesis that density is the main reason for the spread of the pandemic. However, those scholarly articles that incorporated multiple methods and testing found that population density is not a straightforward reason for the spread of coronavirus, but this spread is also contributed to by other confounding factors such as connectivity, crowding, and order. This finding echoes the opinion by Keil (2020, p. 1288) that "there are no linear density-disease relationships here but complex and contradictory ones".

As such, the authors argue that the media (including the leaders) have oversimplified the understanding of population density. In referring to the findings from rigid scholarly articles, the connectivity of humans or network linkages is the most important factor, and attention to this is needed. A density calculation of the total population per space occupied can go upwards, into vertical space. Hence, there are different density calculations for people per floor space area or people per land-use area. To this extent, those from the geographical modelling outlook potentially tend to ignore the use of floor space density but generalise land-use area, especially for a large city that is compounded with many high-rise residential areas. High-rise buildings such as apartments are designed with a high population density per land-use area but relatively lower density per floor-use area. Controlling crowds of people and the use of public spaces, such as issuing orders for ensuring good social distance, wearing protection masks, and using public space according to time booking, has been proven to effectively control the spread of the virus, even in a dense city area. Thus, if such measures happen, they would possibly contribute to misinterpretations of the results.

According to best practice, dense (compact) city planning is intended to cater for economic, social and environmental problems, especially in coping with the phenomena of urban migrants as well as the pace of urbanisation in a city. Dense city planning helps to avoid urban sprawl, leveraging the usage of health and other social facilities, and maintaining the land prices in the city area (Gunasilan, 2020; Yin \& Abdullah, 2020). With the spurious hypothesis that a high density invites the higher spread of coronavirus disease, this article suggests denying it, and that the urban development planning policy should continuously advocate dense city planning as part of moving towards resilient economic and social conditions, environmental sustainability, and human quality of life. Here, the term 'resilient development' becomes the most appropriate to make a city or settlement always ready and able to recover fast from any disasters.

At the spatial planning level, the upcoming NPP and NUP are urged to clarify the order concerning the human level of connectivity linked together through economic, social and commuting relationships (refer Hamidi et al, 2021). It should not leave an ambiguous state such that LAs self-regulate spatial density issues but provide direction on the human level of use and the connectivity of public spaces. It should incorporate dynamic-resilient space planning and design, allowing social and physical distances when needed. Moreover, there should be 
Seng Boon Lim, Jalaluddin Abdul Malek, Mohd Fadzil Abdul Rashid \& Yong Chee Kong

Rethinking Density in Urban Planning: Policy Directions in the Post-Covid-19 Era in Malaysia

a dedicated space for quarantine when the pandemic breaks out. That is a new challenge for the urban planning profession. From the experience of one of the authors engaged in a series of stakeholder engagement sessions, the draft of the fourth NPP still covers density very briefly in relation to its impact on the pandemic. However, the plan will have a section about responding to the postpandemic situation, namely strengthening the national border and food security, promoting a healthy and green lifestyle, strengthening communal public spaces, and ensuring safe environments.

Currently, there are 154 LAs in Malaysia. City Councils make up 11\%, $25 \%$ are Municipal Councils, $3 \%$ are modified LAs, and the majority, $61 \%$ are District Councils (KPKT, n.d.). The lack of professional staff in council administration is an issue (Bahardin et al., 2019). It is suggested that the top-down policies of the NPP and NUP provide further details on population density taxonomy. This taxonomy should cater for different levels of municipalities, such as District Councils, which administer rural-based areas of less than 150,000 people; elaborating the human levels of use and the connectivity of private and public spaces. As aforementioned, this connectivity and order should include the new normality of WFH and social distancing with good human relationships. Whereas there is nothing wrong with continuous advocacy of spatial high-density development, the additional details of density taxonomy and the detailed conditions of human levels of usage and the connectivity of public and private spaces will give confidence to the urban planning practice and related professions. The details to consider include planning a population density with adequate public spaces, such as wider corridors in public housing, more spacious urban parks and playgrounds; and safeguarding hygiene factors, such as safe water and sewage systems, and sanitary physical conditions (Salama, 2020).

\section{CONCLUSION}

The relationship between density and the spread of infectious disease is not a straight line, but is complex and subject to various confounding factors. These include connectivity, crowding and order. Therefore, this article concludes that policies related to urban planning should advocate the provision of a high quality of life in terms of economic, social, and environmental sustainability, which should continue for compact city planning. Having said that, the spatial-level of a high population density-driven policy, as stated under the NPP3 and NUP2, needs to provide further clarification on the order of human levels of connectivity that link together through space, and through economic, social, and commuting relationships. Among the demands that are required to be incorporated are the new normality of the post-COVID-19 era. Apart from having greater accessibility to health and social facilities through dense area planning, the human-to-human relationship is an essential feature in striving towards a better quality of life. 
The limitation of this article is that it is on the review level. Thus, more empirical studies with rigid methodologies are suggested to provide more of a spatial density taxonomy concerning the human level of usage and the connectivity of public and private spaces. However, it is worth noting that this article has contributed to rethinking the spatial urban planning related policies by incorporating density and its relationship to the spread of infectious disease. Policymakers and urban planners could refer to this review and make judgements on future spatial planning, in particular on high-density development that should always attempt to relate to human planning levels. As aforementioned, a highdensity development should incorporate a dynamic-resilient concept, that is, a development that prioritises security, health and a prosperous living environment.

\section{FUNDING}

This article was funded by the Malaysian Ministry of Higher Education (grant number FRGS/1/2019/SS06/UKM/02/2).

\section{REFERENCES}

Almagro, M., \& Orane-Hutchinson, A. (2020). JUE insight: The determinants of the differential exposure to COVID-19 in New York city and their evolution over time. Journal of Urban Economics, (October), 103293.

Bahardin, T. M. I., Alias, Z., \& Abdullah, M. (2019). A systematic review of the issues affecting local government in Malaysia. Journal of Advanced Research in Business and Management Studies, 15(1), 33-40.

Bogle, E. (2020). Families adjust to life at home during Coronavirus. Retrieved February 24, 2021, from https://www.npr.org/sections/pictureshow/2020/04/15/828835862/families-adjust-to-lifeat-home-during-coronavirus

Carozzi, F., Provenzano, S., \& Roth, S. (2020). Urban density and Covid-19. London: London School of Economic and Political Science.

Connolly, C., Keil, R., \& Ali, S. H. (2020). Extended urbanisation and the spatialities of infectious disease. Urban Studies, 58(2), 245-263.

Gunasilan, P. (2020). Covid-19 and its effect on town planning. Retrieved February 20, 2020, from https://www.thestar.com.my/business/business-news/2020/06/27/covid-19and-its-effect-on-town-planning

Hamidi, S., Sabouri, S., \& Ewing, R. (2020). Does density aggravate the Covid-19 pandemic? Early findings and lesseons for planners. Journal of the American Planning Association, 86(4), 495-509.

Jenks, M., \& Dempsey, N. (Eds.). (2005). Future Forms and Design for Sustainable Cities. Burlington, MA: Elsevier.

Jun, S. W. (2020). Experts: Rethink on urban design much needed as Covid-19 reshapes what Malaysians want, need. Retrieved February 20, 2020, from https://www.malaymail.com/news/malaysia/2020/07/10/experts-rethink-on-urban-designmuch-needed-as-covid-19-reshapes-what-malay/1883132

Keil, R. (2020). The density dilemma: there is always too much and too little of it. Urban 
Seng Boon Lim, Jalaluddin Abdul Malek, Mohd Fadzil Abdul Rashid \& Yong Chee Kong

Rethinking Density in Urban Planning: Policy Directions in the Post-Covid-19 Era in Malaysia

Geography, 41(10), 1284-1293.

KPKT. (n.d.). Senarai Pihak Berkuasa Tempatan di Malaysia. Retrieved December 10, 2020, from http://jkt.kpkt.gov.my/en/SUK\%26PBT/Senarai/SenaraiPBT

KPKT. (2016). Rancangan Fizikal Negara Ke-3. Putrajaya: Kementerian Perumahan dan Kerajaan Tempatan.

Krouse, B. Y. L., \& Miller, K. (2021). When will the Novel Coronavirus pandemic be over? Retrieved February 16, 2021, from https://www.womenshealthmag.com/health/a31406983/when-will-coronavirus-end/

Lim, L. L. (2020). The socioeconomic impacts of COVID-19 in Malaysia: Policy review and guidance for protecting the most vulnerable and supporting enterprises. Geneva, Switzerland: International Labour Organization.

Malaymail. (2021). Population density among causes of high Covid positive cases in Selangor, says MB. Retrieved February 24, 2021, from https:/www.malaymail.com/news/malaysia/2021/01/27/population-density-amongcauses-of-high-covid-positive-cases-in-selangor-sa/1944630

Ministry of Health for Malaysia. (2020). R-Naught, high density and mobility of the people in Klang Valley. Retrieved February 24, 2021, from http://covid19.moh.gov.my/sorotan/102020/r-naught-and-high-density--mobility-of-the-people-inklang-valley

ourworldindata.org. (2021). COVID-19 death rate vs. population density. Retrieved February 24, 2021, from https://ourworldindata.org/grapher/covid-19-death-rate-vspopulation-density?time $=2021-01-19$

Peters, M. D. J., Godfrey, C. M., McInerney, P., Soares, C. B., Khalil, H., \& Parker, D. (2015). The Joanna Briggs Institute reviewers' manual 2015: Methodology for JBI Scoping Reviews. South Australia: Joanna Briggs Institute.

Rahman, M. H., Zafri, N. M., Ashik, F. R., \& Waliullah, M. (2020). GIS-based spatial modeling to identify factors affecting COVID-19 incidence rates in Bangladesh. MedRxiv, 1-36.

Ramírez-Aldana, R., Gomez-Verjan, J. C., Bello-Chavolla, O. Y., \& Peterson, T. (2020). Spatial analysis of COVID-19 spread in Iran. PLoS Neglected Tropical Diseases, 14(11), 1-15.

Rapoport, A. (1975). Toward redefinition of density. Environment and Behaviour, 7(2), $133-158$.

Salama, A. M. (2020). Coronavirus questions that will not go away: Interrogating urban and socio-spatial implications of COVID-19 measures. Emerald Open Research, 2, 14. https://doi.org/10.35241/emeraldopenres.13561.1

Shoichet, C., \& Jones, A. (2020). Coronavirus is making some people rethink where they want to live. Retrieved February 24, 2021, from https://edition.cnn.com/2020/05/02/us/cities-population-coronavirus/index.html

Tavernise, S., \& Mervosh, M. (2020). America's biggest cities were already losing their allure. What happens next? Retrieved February 24, 2020, from https://www.nytimes.com/2020/04/19/us/coronavirus-moving-city-future.html

UNDP. (2020). How We Worked from Home. Putrajaya: United Nations Development Programme.

Wheaton, W. C., \& Thompson, A. K. (2020a). Doubts about density: Covid-19 across cities and towns. Retrieved February 20, 2021, from http://dx.doi.org/10.2139/ssrn.3586081 
Wheaton, W. C., \& Thompson, A. K. (2020b). The geography of Covid-19 growth in the US: Counties and metropolitan areas. Retrieved February 20, 2021, from http://dx.doi.org/10.2139/ssrn.3570540

World Health Organization (WHO). (2021). WHO Coronavirus Disease (COVID-19) Dashboard. Retrieved July 11, 2021, from https://covid19.who.int/

Yin, I., \& Abdullah, J. (2020). The development control of urban centre in Kuala Lumpur. Planning Malaysia, 18(3), 313-325.

Received: $17^{\text {th }}$ May 2021. Accepted: $9^{\text {th }}$ July 2021 